\title{
Dynamics of Language and Culture as a Paradigm for Interrogating Igho Identity
}

\author{
Chris Uchenna Agbedo * \\ (University of Nigeria (Nsukka), Nigeria)
}

\begin{abstract}
This paper explores the extent to which language and culture can suffice as an interpretative framework for interrogating the issues and challenges of Igbo identity within the multidimensional context of Nigeria. As a function of individual, group and collective personality, the search for identity, which is both physical and transcendental, can hardly ignore the pivotal significance of language and culture. Nonetheless, realities of contemporary times have tended to provoke a number of issues, which sire a seedbed of identity crisis and by extension gnaws away the centrality of language and culture in identity construction. This is the research problem identified, which we sought to address in this paper. To this effect, we identified language and culture as veritable tools of identity construction. However, the corroding effects of modernity and intervening variables on language and culture have not only divested the latter of their instrumentality but advertently or inadvertently emboldened real-time disruptive tendencies and concomitant exigencies to alter the salient ontological relationships that characteristically define the typical African society. To reverse this ugly trend, we suggest a retooling/re-jigging Igbo language and culture in a manner that would reposition them to reclaim their 'lost paradise' and re-invent them as indispensible integers in the identity construction equation.
\end{abstract}

Keywords: Igbo, language, culture, identity construction

\section{Introduction}

In this paper, we seek to explore the resources of language and culture as a paradigm for forging Igbo identity and leverage on its potentials for deepening advocacy for Igbo unity and development. Hopefully, this paper would provide us an opportunity to utilise the resources of our own social orientation of linguistics in strutting around the subject, which borders on paradigms for Igbo identity, unity and development. We intend to leverage on the concept of 'Onye aghana nwanne ya' (Be your brother's keeper), which is the motto of

\footnotetext{
* Chris Uchenna Agbedo: Professor of Linguistics, Head of Department of Linguistics, Igbo \& Other Nigerian Languages, University of Nigeria, Nsukka, Nigeria. Email: christopher.agbedo@unn.edu.ng, elegberezomida65@gmail.com.
} 


\section{Dynamics of Language and Culture as a Paradigm for Interrogating Igbo Identity}

Ohaneze Ndigbo (an umbrella socio-cultural organisation of Igbo ethnolinguistic group of southeast Nigeria) to show that a dialogic exchange between advocates of Igbo unity and academics (especially of sociolinguistics extraction) may sire a dialectic synergy that could rub off on the advocacy for the unity and development of the Igbo nation. This disposition has encouraged us to verge on the anvil of language/culture and hammer out a paradigm for interrogating Igbo identity and the 'disruptive innovations' that premeditate crisis of Igbo identity and the resultant challenges. Here, we shall attempt to present language and culture as veritable tools to leverage on for constructing and entrenching Igbo identity without glossing over the concomitant challenges. Conceived in terms of a set of underlying assumptions and intellectual structure upon which research and development in a field of inquiry is based, language and culture provide a paradigm for viewing the reality of identity for the Igbo nation. The task before us is to identify those 'disruptive innovations' of our contemporary times that prey on language and culture as veritable tools of identity construction and proffer plausible means for addressing the challenges.

Identity, according to Baker (2003:51) "concerns the shared characteristics of members of a group, community or region. Identity provides the security and status of a shared existence. Sometimes, identity is via dress, religious beliefs, rituals, but language is almost always present in identity formation and identity displays". In essence, language is an index, symbol and marker of identity. In recent times, there has been increased interest in identity as a subject of inquiry in the social and behavioural sciences as clearly attested to in the literature (cf. Edwards, 2009; Omoniyi \& White, 2006; Deckert \& Vickers, 2011; Jacoby \& Ochs, 1995; Connell \& Gibson, 2004). In the context of this work, what is rather of ultimate interest is essentially identifying what actually constitute an Igbo identity.

Whether it is identity deficit ('motivation crisis') wherein the individual experiences a lack of guiding commitments but struggles to establish personal goals and values or identity conflict ('legitimation crisis') wherein the person has several commitments, which prescribe conflicting behavioral imperatives in some situations, such that at least one commitment may have to be betrayed, Ndigbo have been caught up in the wicket of linguo-cultural crossroads. The negative impact of this development on the Igbo identity imposes a requirement on Ndigbo to diagnose this 'pathological condition' with a view to redressing the situation, decapitate the festering virus and prevent it from graduating into a malignant tumour.

\section{The language and identity}

It has been established in literature on language and identity that the language we use forms an important part of our sense of who we are of our identity, (cf. Calhoun, 1994; Edwards, 1985, 2009; Joseph, 2004; Gumperz, 1982; Le Page \& Tabouret-Keller, 1985; 


\section{Chris Uchenna Agbedo}

Kroskrity, 1993; Hooson, 1994; Malesevic, 2002; Brubaker \& Cooper, 2000; Groebner, 2004; Hall \& du Gay, 1996; Jenkins, 2004). Also, the use of language to construct identity has been explored in education (Adger, 1998; Bucholtz, 1999; Fordham, 1998; Toohey, 2000), specifically among bilingual Spanish-English speaking students (Zavala, 2000) and in bilingual Spanish-English society as a whole (Johnson, 2000; Morales, 2002; Stepick \& Stepick, 2002; Valdés, 2000; Zentella, 2002). Here, identity is understood to be plural, dynamic, non-fixed and socially constructed (e.g. Edwards, 2009). Identity is at the heart of the person, and the group, and the connective tissue that links them. People need 'psychosocial anchors' as Edwards (2009:2) observes and one such anchor, a very powerful one in fact, can be language. Indeed, as Joseph (2004:224) observes, any study of language needs to take consideration of identity if it is to be full and rich and meaningful, because identity is itself at the very heart of what language is about, how it operates, why and how it came into existence and evolved as it did, how it is learned and how it is used, every day, by every user, every time it is used.

A number of scholars have been attracted to studies on language and identity. A discussion by Jenkins (2004:8) throws a little more light upon the recent salience of identity; noting that 'identity' became one of the unifying themes of social science during the 1990s, and shows no signs of going away. Everybody has something to say: anthropologists, geographers, historians, philosophers, political scientists, psychologists, sociologists... Identity, it seems, is bound up with everything. Identity at one level or another is central to all 'human' or 'social' sciences, as it also is in philosophical and religious studies, for all these areas of investigation are primarily concerned with the ways in which human beings understand themselves and others. This is so, given that language itself is such a broad topic, as Joseph (2004:13) has pointed out, language and identity are 'ultimately inseparable'. Indeed, since language is central to the human condition, and since many have argued that it is the most salient distinguishing characteristic of our species, it seems likely that any study of identity must surely include some consideration of it.

According to Cerulo (1997), the study of identity forms a critical cornerstone within modern sociological thought. Introduced by the works of Cooley and Mead, identity studies have evolved and grown central to current sociological discourse. Microsociological perspectives dominated work published through the 1970s. Sociologists focused primarily on the formation of the 'me', exploring the ways in which interpersonal interactions mold an individual's sense of self. Recent literature constitutes an antithesis to such concerns. Many works refocus attention from the individual to the collective; others prioritize discourse over the systematic scrutiny of behavior; some researchers approach 
identity as a source of mobilisation rather than a product of it; and the analysis of virtual identities now competes with research on identities established in the co-present world.

It equally needs to be pointed out that in identity studies, collective identity is a concept grounded in classic sociological constructs: Durkheim's 'collective conscience', Marx's 'class consciousness', Weber's Verstehen, and Tonnies' Gemeinschaft. Cast in this theoretical mould, the notion addresses the 'we-ness' of a group, stressing the similarities or shared attributes around which group members coalesce. Early literature approached these attributes as 'natural' or 'essential' characteristics-qualities emerging from physiological traits, psychological predispositions, regional features, or the properties of structural locations. Members of a collective identity are believed to internalise these qualities, suggesting a unified, singular social experience, a single canvas against which social actors constructed a sense of self. The foregoing, we assume, has effectively established a propitious basis for addressing the language-identity interface and which provides us the platform to probe deeper into the bigger issue of disruptive innovations that constitute a challenge to Igbo identity construction through the instrumentality of Igbo language and culture.

The realities of disruptive innovations, disruptive technologies, and digital disruptions as defining features of contemporary times tend to depict the historical accident of colonialism and its disruptive impacts on the linguo-cultural aspects of Igbo identity. The interconnectedness of these issues and how they morph into a generic bugbear that undermines the instrumentality of language and culture to identity construction and by extension engender a sense of identity crisis among Ndigbo in contemporary times would be the focus of discussion in the subsequent sections.

\section{Colonialism and its disruptive proboscis}

Colonialism brought with it the instrumentality of linguistic and cultural imperialisms. The colonial masters foisted their language and culture on their colonial societies. In our own peculiar context, it was a language policy that enthroned the English language as official language with an in-built mechanism that decapitated the indigenous languages and divested them of all utilitarian values. The impact of this policy has led to a chain of events, which we capture in sociolinguistic discourses as bilingualism, language attitude, language choice, language shift, language endangerment, language attrition/loss, language death, language revitalisation. Of particular concern are language endangerment and language loss, which stare the Igbo menacingly in the face.

The concept of imperialism has been the most powerful force in world history over last four or five centuries. From the colonial to post-colonial era or neo-imperialism, the world has been on a constant move as the imperialists changed their grounds and strategies in 


\section{Chris Uchenna Agbedo}

imperialistic rules; yet, the ultimate objective has remained the same - to rule and exploit the natives with their multifaceted linguistic, technological, economic, cultural, and military dominance. Through dominance with these, they have been, to a large extent, successful in entrenching their linguistic, racial and cultural superiority. In this war of imperialism, the rule of engagement has been largely linguistic and cultural in character because the choice of language and the use to which it is put are central to a people's definition of itself in relation to its natural and social environment, indeed in relation to the entire universe.

When Phillipson (1993) formally introduced the term 'linguistic imperialism' in his book, Linguistic Imperialism, he examined the dynamics of English Language Teaching (ELT) policy and its development in most colonial countries; explored the potential for English teaching as a vehicle for western capitalist hegemony; how the elites in different countries encouraged education in English as a means of overcoming perceived problems arising from linguistic pluralism. He coined the terms linguicism to refer to the privileging of one language (e.g. English or French) at the expense of others, usually indigenous languages; linguistic genocide or linguicide, which refers (in the field of language displacement, language death, and degeneration) to the systematic replacement of an indigenous language with the language of an outside, dominant group, resulting in a permanent language shift and the death of the indigenous language.

The literature has been awash with researches on the effects of linguistic imperialism (as direct offshoot of European colonialism) on the indigenous languages of the colonies. In fact, Migge \& Léglise (2007) have provided the following list: Césaire (1950), Fanon (1952), Spencer (1971a \& b, 1985), Calvet (1974, 1987), Ngugi (1986, 1993), Pennycook (1994, 1998), Phillipson (1992), Skutnabb-Kangas \& Phillipson (1995). These works have focused on the linguistic and social inequalities that had emerged in the former colonies of the world due to European imperialist expansion, and how they continue to affect the linguistic and social make up of these regions, the nature of local language policies, and the status and development of non-European languages. Even when many of these regions have since gained political independence, Phillipson (1992) observes that access to education, knowledge, power and self-sufficiency of indigenous populations continues to be highly limited. Moreover, most of the newly independent countries faced many difficulties in relation to decolonisation as the twin factors of economic pressure from the former colonisers and opposition to decolonisation from local elites, (who would hardly stand the risk of losing their privileged elitist positions) have effectively conspired to maintain colonial social and linguistic practices.

The European colonisers and their indigenous collaborators who were consistently identified with the positive or prestigious values were firmly located at the top of the social 
hierarchy, holding the power in the society and enjoying the highest social standing within it, whereas the colonised, being identified with the subordinate position, were assigned low social status and granted little or no social power. Calvet (1987:72) identifies two steps involved in linguistic colonisation. The first one, called 'vertical step' refers to the social spread of the language. The European language first spread into the 'upper classes' of the colonised people, i.e. surrogates of colonial power, and later percolated down the lower wrung of the 'lower class' members. The second one, called 'horizontal step', involves its geographic spread whereby the colonial language is diffused from the capital to small cities and from there to villages. This linguistic colonialism got instilled in their colonial subjects through a special colonial education system, which was also constantly being furthered, reaffirmed, reinforced and generated by a range of other social and linguistic practices.

The implications of this colonialism-driven asymmetrical social ideology are many and varied. First, it gave rise to a (new) language hierarchy in which the language of the coloniser was inscribed as the most prestigious language and came to dominate the administrative and mercantile structure of each colony on the one hand, and firmly assigned African languages to the bottom of language hierarchy thereby freezing their opportunities for functional complementarities and developments on another hand. People's attachment to these indigenous languages was considered irrational and a sign of ignorance and resistance to civilisation. By contrast, the learning of the colonial language was portrayed as an asset in that it presumably "opens up a person's mind to the (modern world)", as Calvet (1974) observes, and made them civilized, modern human beings. Second, colonial language practices also brought about the demise of many languages. This sociolinguistic reality is sometimes referred to as linguistic genocide or linguicide in the field of language displacement, when it involves the systematic replacement of an indigenous language with the language of an outside, dominant group, resulting in a permanent language shift and the death of the indigenous language. Third, it led to the creation of new languages such as pidgins and creoles. Fourth, in some settings, colonial language practices also gave rise to a change in the relationship between the different local languages.

In summary, the colonial policies constituted a kind of disruptive innovations that reshaped the linguistic and cultural landscapes of the indigenous societies in a number of ways that were instrumental to dissociating the people from their linguo-cultural roots and traditions of solidarity. The impacts of the disruptive tendencies of the colonial policies extend to the present and made manifest in the current state of most indigenous languages of ex-colonial societies of commonwealth Africa and Asia. The threat of language endangerment in contemporary times is real. According to Agbedo (2019), Stephen Wurm, editor of UNESCO's Atlas of the World's Languages in Danger of Disappearing classifies 


\section{Chris Uchenna Agbedo}

language endangerment into five levels: (i) Potentially endangered: when children of a cultural area start preferring the dominant language and learn the obsolescing language imperfectly; (ii) Endangered: if the youngest speakers are young adults and there are no or very few child speakers; (iii) Seriously endangered: when the youngest speakers are middle-aged or past middle age; (iv) Terminally endangered or moribund: if there are only a few speakers left; (v) Dead/extinct: when there are no speakers left at all.

Other factors have been identified, which may contribute to the assessment of language endangerment. Fishman's (1991) Graded Intergenerational Disruption Scale (GIDS) postulates a continuum of 8 stages for assessing language loss or disruption, and with which to guide any plan of action that would lead to turning around the fate of an endangered language. A number of other guides in evaluating language endangerment followed suit: Brenzinger (1992); Landweer (1998); Lewis \& Simons (2010). The Expanded Graded Intergenerational Disruption Scale (EGIDS) developed by Lewis \& Simons (2010) for comprehensive global assessment of the state of the world's languages was intended to address the problems arising from UNESCO's framework, Fishman's GIDS, as well as cater for a wider range of peculiarities with minority languages and their situations. The implication of all this is that language endangerment is a reality and suggestions for reversing the ugly trend have therefore not been lacking. One of such suggestions is a call on the owners of such languages to develop renewed interests in their languages. For Bamgbose (1993:29), "when all is said and done, the fate of the endangered languages may well lie in the hands of the owners of the language themselves and in their will to make it survive."

The gale of language endangerment sweeping across the global linguistic landscape with the effortless ease of a hurricane lapping up with relish the rich plains of the savanna would not have possibly left Ezikeoba dialect of Igbo intact. The signs of this 'locust invasion' are visible even to the blind. The disruptive impacts of colonial policies have equally been significant in the cultures of the peoples in post-colonial societies. In this regard, the Igbo nation is not an exception. In particular, the Ezikeoba cultural landscape has witnessed the corroding effects of digital disruptions in countless ways: mores, lore, norms, dress codes, worships, family ties, proverbs, anecdotes, wellerisms, rituals, divination, etc.

Another disruptive factor that has largely been ignored in extant literature on language and identity is politics. For instance, Oloso (2017) situates the role of politics in the construction and manifestations of the linguistic and ethnic identities of the people of Ilorin Emirate to determine the extent to which ethnic groups native to the community identify with their ethnic ancestries and heritage languages. Contrary to the claims of existing literature, which posits an inseparable link between language and identity, hence, language loss constitutes identity loss, Oloso observes that allegiances to ancestry whose language 
are lost in Ilorin Emirate demonstrate that language and identity are indeed separable given that language loss did not constitute identity loss for a higher number of respondents of non-Yoruba ancestry.

The foregoing discussion has painted in lurid colours how colonialism and its multi-faceted proboscis has dealt lethal blows on our indigenous languages and cultures, diminished the cherished values of ancestry and overall human essence of the African. The seriousness of the prevailing situation derives from the fact that language is not simply an assortment of words but an entity that connects an individual to his family, identity, culture, music, beliefs and wisdom. It is the conveyor belt that transmits history, traditions, customs and folklore from one generation to another. Without language, no culture can sustain its existence, hence the indissoluble natural link between language and identity. "If you talk to a man in a language he understands, as Nelson Mandela posited, that goes to his head. If you talk to him in his mother language, it goes to his heart."

The mother tongue plays a crucial role in shaping an individual's personality as well as his or his psychological development, thoughts and emotions. Our childhood is the most important stage of our lives and children can comprehend concepts and skills that are taught to them in their mother tongue quite fast. In fact, many psychologists are of the opinion that a strong bond between a child and his or her parents (especially the mother) is established through exhibition of love, compassion, body language and verbal communication, i.e. language. According to education specialist, Hurisa Guvercin, "When a person speaks his mother tongue, a direct connection is established between heart, brain and tongue. Our personality, character, modesty, shyness, defects, skills, and all other hidden characteristics become truly revealed through the mother tongue because the sound of the mother tongue in the ear and its meaning in the heart give us trust and confidence". UNESCO Director General Irina Bokova believes that, "mother languages in a multilingual world are essential components of quality education, which in itself is the foundation for empowering women, men and their societies".

In the words of Felix Marti (Chair, International Linguapax Committee, UNESCO), each language expresses one of many possible human wisdoms. Languages are at once interpretations of reality, mythical and symbolic constructs, settings for rational life, expressions of community identities, territories for communication and dialogue. Languages are the most prodigious productions of human creativity. They must therefore be considered a common treasure of humanity. Each language is the heritage of the community that expresses itself in that language, but it is also the heritage of the whole of humanity. Some linguists have warned of the probable disappearance of 1,000 languages in the next 20 years. This envisaged linguistic disaster is as serious as the loss of biodiversity if not more serious given that languages are the most valuable expression of the human 


\section{Chris Uchenna Agbedo}

spirit. This explains why the challenge of identity crisis engendered by colonialism and its multi-faceted proboscis needs to summon a renewed kind of galvanic and combative purposefulness on our part to reverse the ugly trend and re-invent our languages and cultures, restore and re-invest them with the pristine treasures, of which colonialism had robbed them.

Lack of unity among sub-ethnic groups of Ndigbo complemented by wrong perceptions, notions and inherited biases has been a formidable challenge to Igbo identity. Such ignoble and uncharitable stereotypical terms as nwa onye Igbo, waawa, onye awurak' (onye agbel'), nwa Nsuka / Abakeleke, ogwu ego, onye imezi, onye ngwa, etc. ${ }^{1}$ represent default lines of pristine prejudices, which tend to define sub-ethnic group relationships of Ndigbo both within the ancestral confines and in the Diaspora.

\section{Going back to linguistic and cultural roots}

A number of steps at resolving an identity crisis have been suggested by Wikihow (https://www.wikihow.com/resolve-an-identity-crisis).

We have observed elsewhere (Agbedo, 2019) that the impact of over 100 years of language policy that prohibited and punished the use of indigenous languages in the schools of ex-colonial societies such as ours is evident in language shift as a precursor to language endangerment, language loss, and language death, which ultimately makes language revitalisation an inescapable option. Language revitalisation is the rescue of a 'vanishing', 'disappearing' or 'dying' language. The success story of Hebrew, Algonquin, Gitksan (Tsimshianic), Kwak'wala (Wakashan), Inuktitut (Inuit), Māori Indigenous languages, is a pointer to the fact that it is the sustained efforts of communities that shape and determine the goal and success of any language revitalisation project.

The success of this project is dependent on our readiness to change our negative attitude towards our language and culture. To mitigate the undesirable effects of negative attitude, the Principle of Attitude Engineering (PAE), notes Agbedo (2019:321), is proposed, which implies "the systematic use of sociolinguistic and psycholinguistic knowledge, principles and techniques to determine attitudes of government and the speakers of various languages in a language contact situation and the use of the findings as input for the design and implementation of a programme to effect polarisation of attitudes in the direction of a desired policy outcome". PAE is intended to bring about a change of mindset, which has

\footnotetext{
(1) They are pejorative terms used by people from different parts of Igbo speech community to refer to one another: awurak (people who buy and sell palm kernel), agbel, ijeke ebee, ala wu otu (people from western, south \& eastern parts of Igbo speech community), waawa (people from northern part of Igbo), Onye Ngwa (carnivorous humans), Nwa Nsukka, Abakeleke (indigenes of Nsukka, Abakaliki cultural zones perceived as backward), ogwu ego (money ritualists), onye imezi (a timid and backward person).
} 


\section{Dynamics of Language and Culture as a Paradigm for Interrogating Igbo Identity}

been repeatedly presented as a desired social and economic necessity in the African context by a number of scholars of African extraction. For such scholars (Ngugi, 1995; Alexander, 2005), Africans need a change of mindset to get off the hooks and manacles of the dilemma of contradictions, which casts Africa and its people in the mould of a continent endowed with natural resources of considerable variety, quantity and quality but remains terminally poor. For instance, Ngugi (1995) attributes the negative attitudes of Africans to education in the mother tongue in favour of English to the colonial mentality, which sees English, 'the language of imperialism' as the only medium for intellectual and academic discourse. Alexander (2001) in Chumbow (2012) captures this sour state of affairs in this rhetorical poser: "How can we transform the climate of opinion so that we can shift the colonial minds from the groundless belief that only knowledge, which is packaged in the languages of the colonial conquerors, is worthwhile knowledge?"

\section{Conclusion}

In this paper, we have examined issues and challenges of language and culture as tools for constructing Igbo identity and explored the extent to which an Igbo identity can be leveraged upon for forging Igbo unity and by extension deepen advocacy for development. We sought to establish an indissoluble link between language and identity but modified this interface by recognising the role of politics as an intervening variable in the constructions and manifestations of linguistic, ethnic, religious and other identities. Nonetheless, the role of language and culture as tools for Igbo identity construction has been diminished almost irredeemably by the historical antecedent of colonialism amply complemented by the disruptive innovations of contemporary times. To this effect, partisan interests, sectarian cleavages, and other social considerations have taken the steam off the ontological relationships immanent in a typical African society of Igbo, which is clearly defined by her language and culture.

The concomitance of identity crisis and its vitiating impacts on the instrumentality of language and culture to Igbo identity construction imposes a requirement on Ndigbo to wake up to their responsibility of keeping alive their language and culture. This implies, inter alia, a renewed kind of attitude engineering that makes room for a change of mindset in favor of Igbo language and culture and dismantling of the enslaving colonial mentality. This sustained approach would undoubtedly re-invent and re-tool Igbo language and culture and re-position them as functional paradigms for Igbo identity construction, unity, and development. 


\section{Chris Uchenna Agbedo}

\section{References}

Adger, C. T. 1998. Register shifting with dialect resources in instructional discourse [A]. In S. Hoyle \& C. T. Adger (eds.), Kids talk: Strategic language use in later childhood [C]. New York: Oxford University Press, 151-169.

Agbedo, C. U. 2019. Multilingualism and national development in Nigeria: Issues and challenges [M]. Nsukka: University of Nigeria Press Limited.

Alexander, N. 2005. Key issues in language policy for Southern Africa [A]. In T. Richard \& S. Fitchat (eds.) The intellectualisation of African languages: The African Academy of Languages and the implementation of the Language Plan of Action for Africa [C]. Cape Town: PRAESA.

Block, D. 2006. Identity in applied linguistics [A]. In T. Omoniyi \& G. White (eds.), The sociolinguistics of identity [C]. London: Continuum, 103-118. Retrieved from https://cvc.cervantes.es/literatura/ cauce/pdf/cauce24/cauce24_03.pdf

Brenzinger, M. 1992. Language Death: factual and theoretical explorations with special reference to East Africa [M]. Berlin: Mouton de Gruyter.

Brubaker, R. \& F. Cooper. 2000. Beyond 'identity' [J]. Theory and Society, 29(1): 1-47.

Bucholtz, M. 1999. "Why be normal?": Language and identity practices in a community of nerd girls [J]. Language in Society, 28(2): 203-225.

Calhoun, C. 1994. Social theory and the politics of identity [M]. Oxford: Blackwell.

Cerulo, K. A. 1997. Identity construction: New issues, new directions [J]. Annu. Rev. Sociol, 23(1): 385-409.

Connell, J. \& C. Gibson. 2004. Deterritorializing place and identity [J]. Progress in Human Geography, 28(3): 342-361.

Chumbow, B. S. 2012. The challenge of linguistic diversity and pluralism: The tier stratification model of language planning in a multilingual setting [A]. In A. Lopez-Varela (ed.), Social sciences and cultural Studies - issues of language, public opinion, education and welfare [C]. IntechOpen, 326-346.

Edwards, J. 1985. Language, society, and identity [M]. New York: Cambridge University Press.

Edwards, J. 2009. Language and identity: An introduction [M]. New York: Cambridge University Press.

Fishman, J. A. 1991. Reversing language shift [M]. Clevedon, UK: Multilingual Matters Ltd.

Fordham, S. 1998. Speaking Standard English from nine to three: Language as guerilla warfare at Capital High [A]. In S. Hoyle \& C. T. Adger (eds.), Kids talk: Strategic language use in later childhood [C]. New York: Oxford University Press, 205-216.

Groebner, V. 2004. Der Schein der Person: Steckbrief, Ausweis und Kontrolle im Europa des Mittelalters [M]. Munich: Beck.

Gumperz, J. 1982(ed.). Language and social identity [M]. Cambridge: Cambridge University Press.

Hall, S. 1996. Introduction: Who needs identity? [A]. In S. Hall \& P. du Gay (eds.), Questions of cultural identity [C]. London: Sage, 8-10.

Hall, S. \& P. du Gay. 1996. Questions of cultural identity [M]. London: Sage.

Hooson, D. 1994. Geography and national identity [M]. Oxford: Blackwell. https://searchcio. techtarget. com/definition/disruptive-innovation.

Jenkins, R. 1997. Rethinking ethnicity [M]. Thousand Oaks, CA: Sage.

Jenkins, R. 2004. Social identity [M]. London: Routledge.

Jacoby, S. \& E. Ochs. 1995. Co-construction: An introduction [J]. Research on Language and Social Interaction, 28(3): 171-183

Johnson, F. L. 2000. Speaking culturally: Language diversity in the United States [M]. Thousand Oaks, CA: Sage Publications.

Joseph, J. 2004. Language and identity: National, ethnic, religious [M]. Basingstoke: Palgrave Macmillan.

Kroskrity, P. 1993. Language, history and identity: Ethnolinguistic studies of the Arizona Tewa [M]. Tucson: University of Arizona Press. 


\section{Dynamics of Language and Culture as a Paradigm for Interrogating Igbo Identity}

Landwear, M. L. 1998. Indicators of Ethnolinguistic Vitality: Case study of two languages-Labu and Vanimo [A]. In N. Ostler (ed.), Endangered Languages: What Role for the Specialist? Proceedings of the Foundation for Endangered Languages (FEL) Conference [C]. Edinburgh, 64-72.

Le Page, R. \& A. Tabouret-Keller. 1985. Acts of identity [M]. Cambridge: Cambridge University Press.

Lewis, M. P. \& G. F. Simons. 2010. Assessing endangerment: expanding Fishman's GIDS [J]. Revue roumaine de linguistique, 55(2): 103-120.

Malesevic, S. 2002. Identity: Conceptual, operational and historical critique [A]. In S. Malesevic \& M. Haugaard (eds.), Making sense of collectivity: Ethnicity, nationalism and globalization [C]. London: Pluto Press, 195-215.

Migge, B. \& I. Léglise. 2007. Language and colonialism. Applied linguistics in the context of creole communities [A]. In M. Hellinger \& A. Pauwels (eds.), Language and communication: Diversity and change, handbook of applied linguistics [C]. Berlin: Mouton de Gruyter, 297-338.

Morales, E. 2002. Living in Spanglish: A search for Latino identity in America [M]. New York: St. Martin's Press.

Ngugi, W. T. 1986. Decolonizing the mind: The politics of language in African literature [M]. London: James Curry.

Ngugi, W. T. 1993. Moving the centre: The struggle for cultural freedom [M]. London: James Curry.

Ngugi, W. T. 1995. Scars of conquest/masks of resistance. New York: OUP.

Oloso, Y. M. 2017. Politics of language and identity in Ilorin Emirate, Nigeria [D]. Ph.D thesis, Department of Linguistics and African Languages, University of Ibadan, Nigeria.

Omoniyi, T. 2006a. Hierarchy of identities [A]. In T. Omoniyi \& G. White (eds.), The sociolinguistics of identity [C]. London: Continuum, 68-74.

Pennycook, A. 1994. The cultural politics of English as an international language [M]. London: Longman.

Pennycook, A. 1998. English and the discourses of colonialism: The politics of language [M]. London: Routledge.

Phillipson, R. 1992. Linguistic imperialism [M]. Oxford: Oxford University Press.

Skutnabb-Kangas, T. \& R. Phillipson (eds.). 1995. Linguistic human rights: Overcoming linguistic discrimination $[\mathrm{M}]$. Berlin: Mouton de Gruyter.

Spencer, J. 1971a. West Africa and the English language [A]. In J. Spencer (ed.), The English language in West Africa [C]. London: Longman, 1-34.

Spencer, J. 1971b. Colonial language policies and their legacies [A]. In T. Seboek (ed.), Linguistics in Sub-Saharan Africa [C]. The Hague: Mouton, 537-547.

Spencer, J. 1985. Language and development in Africa: The unequal equation [A]. In N. Wolfson \& J. Manes (eds.) Language of inequality [C]. Berlin: Mouton Publishers, 387-397.

Stepick, A. \& C. D. Stepick. 2002. Power and identity: Miami Cubans [A]. In M. M. Suárez-Orozco \& M. M. Páez (eds.), Latinos: Remaking America [C]. Berkeley: University of California Press, 75-92.

Toohey, K. 2000. Learning English at school: Identity, social relations and classroom practice. Clevedon: Multilingual Matters.

Valdés, G. 2000. Bilingualism and language use among Mexican Americans [A]. In S. L. McKay \& S. C. Wong (eds.), New immigrants in the United States [C]. Cambridge: Cambridge University Press, 99-136.

Zavala, M. V. 2000. Puerto Rican identity: What's language got to do with it? [A]. In S. Nieto (ed.), Puerto Rican students in U.S. schools [C]. Mahwah, NJ: Lawrence Erlbaum Associates, 115-136.

Zentella, A. C. 2002. Latin languages and identities [A]. In M. M. Suárez-Orozco \& M. M. Páez (eds.), Latinos: Remaking America [C]. Berkeley: University of California Press, 321-338. 